\title{
構造のフォルムと幾何学*
}

\section{Structural Form and Geometry}

$$
\text { 三 } \underset{\text { Koryo MIURA }}{\text { 浦 }} \text { 公** }
$$

\section{はしがき}

フィレンツェのアカデミア美術館を訪れてミケラン ジェロの未完の彫像（第 1 図）を見る人は，おそらく 雕刻に対するこれまでとは違った感懷をいだいてその 場を去るにちがいない。をれは彫刻というよりは大理 石の中に本来埋もれていた像を掘り起こしたような感 じなのである，漱石の“夢十夜”，の中にあ護国寺の山 門で運慶が仁王を彫る話として同様のこよが書がれて あるから，天才の作品には，自然の中の本質的なフォ ルムへの接近というととで特徽付けられる何物かがあ るに違いない,

このととは“美のフォルム”の創造にたちむかう彫

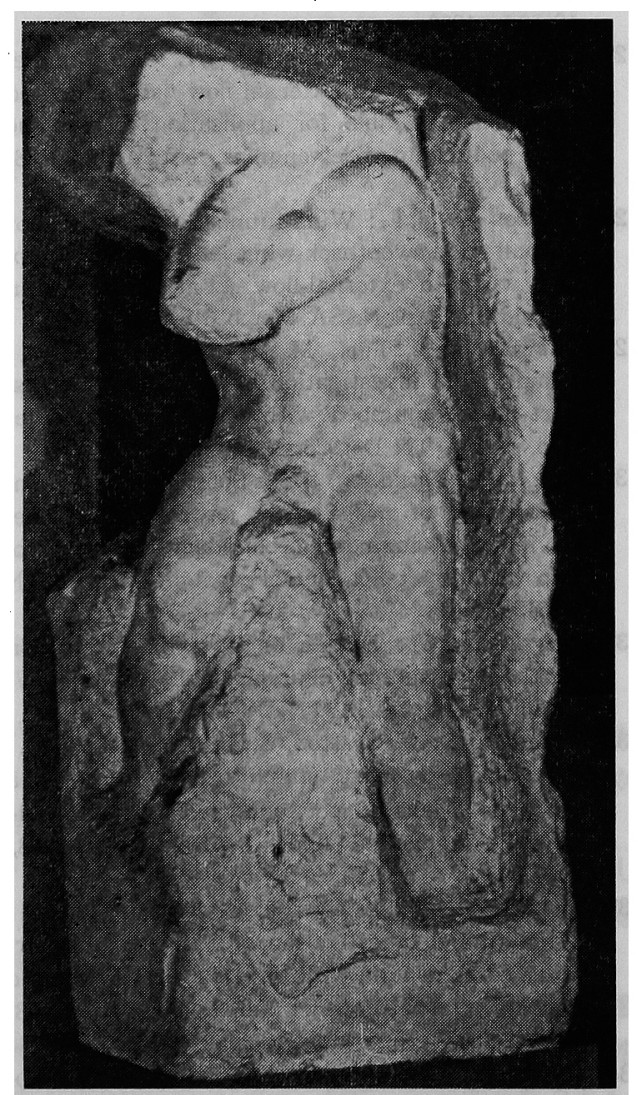

第1図「囚人」ミケランンジェロ作，大理石，アカデミア， フィレンツェ藍

* 昭和 46 年 5 月 13 日原稿受理

** 東京大学宇宙航空研究所
刻家にとってはもちろん，“構造のフォルム”の創造 を対象とするわれわれ構造家にとってあひとしく思惟 させるあのを含んでいる. 加らの用いる道具がのみ とつちであり，われわれの用いるのは数学と力学であ る違いはあるにしてす，本質的には共通のあのがあ る.なぜならば，両者はとすに三次元空間のきめられ た領域によって規定されるが，彫刻はその領域を通し て人間の内面的なものを表現し，構造はその領域に内 在する応力場によって構造の概念として完成するから である.

構造のフォルムを創造するための数学の諸分野で最 も重要なのは，第一に幾何学であり第二に変分学であ ると思われる。これは，棈造概念はその幾何学的形状 とそれに内在する一次的な応力場によって表現される とと，そしてその形状の最適化や洗練が変分原理によ って決定されるる場合が最も一般的であることから明ら かであうう。

構造のフォルムの創造という本来は正面切った仕事 が現代ではほとんどかえりみられず，構造の研究即解 析的研究という傾向怔大方を支配していることは一つ の偏りであると思われるたしかにフォルムは三次元 エークリッド幾何学の簃しい法則に支配され，プラト

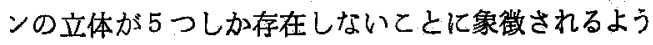
に，意味のあるフォルムは極めて限定的であるととが この方向の研究を挫けさせるに違いない．しかしなが ら一方では新しい材料が登場し，新しい環境への挑戦 が行なわれようとするとき，新しい構造のフォルムの 生まれる可能性は少加らず閏けているように思われ る. 20 世紀の材料には少なくともチンクェチェント* の大理石には無いフォルムが埋っているはずである.

この稿では, “不当にす無視されている幾何学”が 基本的な構造のフォルムと如何に関係しているか，ま たそれが新しい構造のフォルムの創造に如何に役立ち 得るかをいくつかの例によって示そう。な枚筆者自身 この問題に深くかかわり合いを持っているのでとれ は筆者の立場から書かれ，客観性を必要とするレビュ 一なる看板は本稿にはふさわしくないかむしれない。

* 篮期ルネッサンス 


\section{1. 構造のフォルムの創造}

詳諭に入る前に，構造の歴史のなか構造のフォル ムの創造のいくつかを振り返って見るてとは無益では 無いであるう.

アーチは，古典芸術の中で完壁な域までに達するこ とのできた応用力学上の主要な発見であるとされてい る(第2図).アーチは人間にとってドラマチックな印 象を与えるが故に，多くの伝説はこの構造概念が悪魔 のな甘る仕事として伝えている．科学的にはある偶然 の経験とその観察を普遍化することのできた人智に塀 するのが妥当であろう．正縮にしか倬かない石という 材料を用いて，王縮応力が主として働くようなフォル ムを導いたととは，アーチが確かな工学理論化基つい た創造物であることの証拠である.またアーチはその
裹返しとして，毣垂曲線の幾何学または变分学上の等 問問題として引張応力のみの倕くフォルムと深い関連 を有している.

アーチの発見より数干年を経た現代においても，な お新しい粠造概念の発見を示すてとができる. 第 3 図 は, ラングレー・テンション・シェル (Langley's tension shell) 之呼ばれる惑星大気突入のために考案され た機体である. 惑星大気密度の情報が不確実であるこ とにより，弾道係数 $\left(W / C_{D} A\right)$ の極めて小さい機体を 用いることが良いと考えられた，そのような機体は， 大気の性質の湘定の十分な時間を加せぎ，惑星表面に

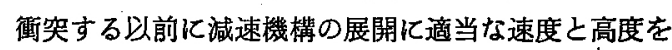
得るととができるのである.

第 3 困に示したテンション・シェルによる機体は, 先端の部分のペイロードと, 中央部の笠状の薄いシェ

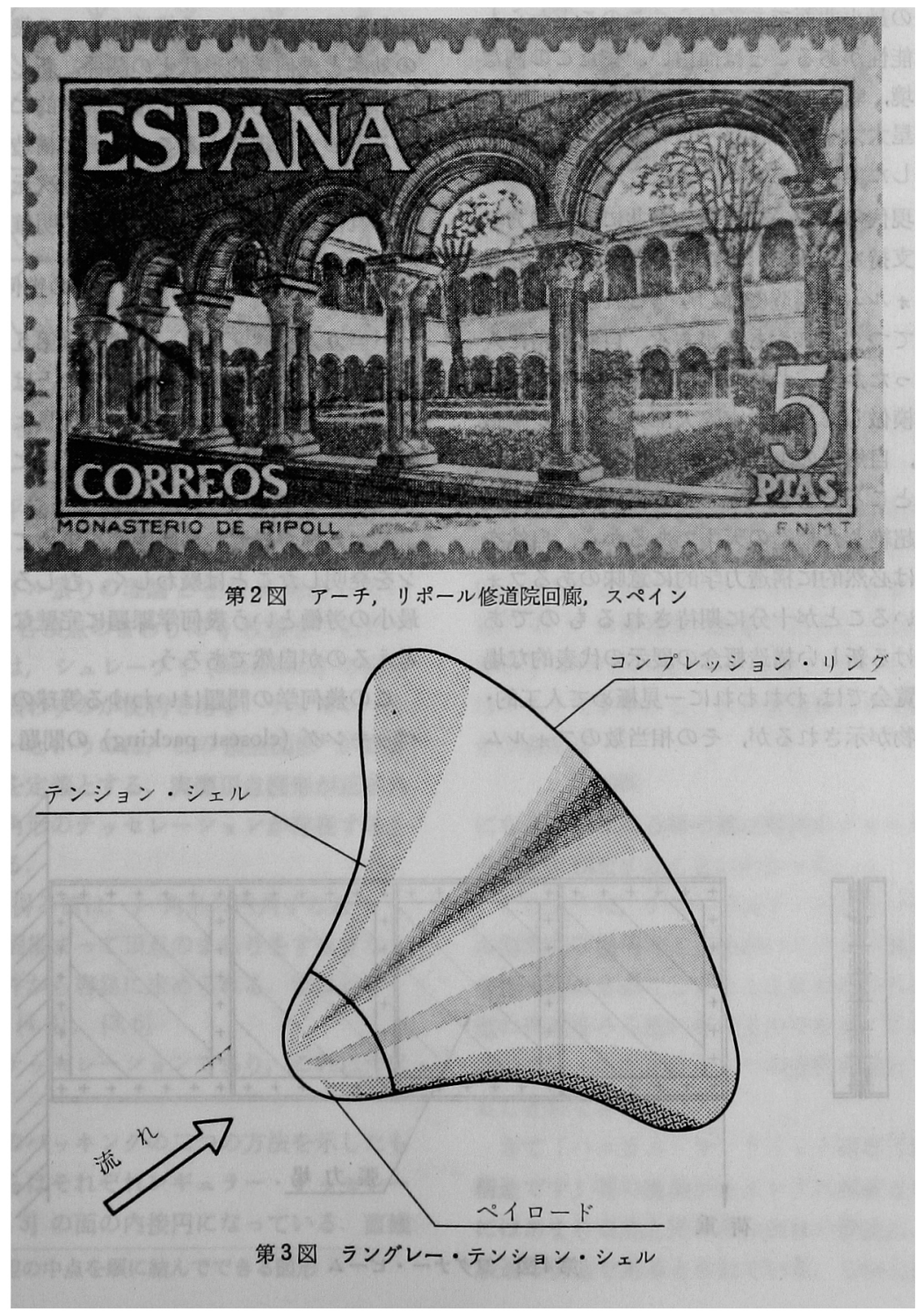


ル，後縁のリングからなっている. あし円錐状の薄い シェルが用いられるならば，笑入の際の空気圧力によ りシェル要素には压縮応力が生ずるから，極端に薄い シェルの設計は挫屈が基準になるであろう.したがっ て重量軽減には限界がある。すし第3园のような形状 リシェルが用いられると，乙れは負のガウスの曲率を 有するから，母線の形状によってはいたるところ引張 㤂力が作用するようにするととができる.したがって このシェルは弾性的に安定で, 設計基準は材料強度を とるととができ，構造重量をそして弾道係数をかなり 小さくすることが可能である. とのテンション・シェ ルの形状は，压力分布・材料の異方特性・忘力のとり 万によってその平衡条件から決定されるが，母線の形 状がだいたいにおいて照垂曲線に近いことが予想され 実際そのようになる，㲘垂曲線の回転曲面は，回転曲 面として唯一の最小曲面であるから，てのことからあ 重量軽減の可能性があることは面白い。またこの例な どは新しい環境，新しい材料，新しい構造のフォルム の結合を，惑星大気・複合材料・テンション・シェル のかたちで示した典型であるといえよう。

以上古代と現代の二つの構造概念が共に純料沉力学 理諭によって支持されるか，または導かれるのを見 た. 構造のフォルムの創造にはしかしてれとは全く異 種の経路を経てつくられるあのがある. 自然は常に人 間の教師であったから，われわれは自然における構造 形態の多くを模做してきた. 実際大部分のシェル構造 のフォルムが，自然界の生物構造の模做であることは 万人の認めるとてろである. あちろん自然自体は人間 よりはるかに超絶した構造の天才であるから，自然を 模做することは必然的に構造力学的に意味のあるフォ ルムとなっていることが十分に期待されるすのであ る. 建築における新しい構造概念の展示の代表的な場 である万国博覧会ではわれわれに一見極めて人工的. 独創的な構造物が示されるが，その相当数のフォルム
は自然界におりる構造のフォルムの模做であるといっ て良いであろう，実際われわれは，顕微鏡下に各種の 佳藻類をもちこむととにより，現在および末来の万国 博建造物の原形を大抵見出すととができるのである.

いずれにせよ，構造のフォルムを導く一般的な方法 は恐らくないであろう．ある場合には力学理論が先行 するかも知れないし，またある場合には幾何学が主導 するかむ知れない．これに関してわれわれは，ワグナ 一・ビーム（第 4 図）によって代表されるこの種構造 の概念は，この種の構造が挫屈後も耐荷能力が增大す るという観察が先行して概念が生まれ，その理論付け として張力場理論が展開された絓緯を想起すべきであ ろう.

筆者は以下の数節において，幾何学の原理によって 導かれる幾つかの基本的な構造のフォルムを示そう. これらはサンドイッチ構造のコアの幾何学でありそ の効率之幾何学的形状との関係，新しい構造のフォル ムの創造等である.コアは幾何学的には不連続群から なるものと表現できるとと，その構造としての効率の 評価が統計的な和である単一の無次元量によっておて なわれ得るととが，問題を極めて明確にしている.

\section{2. ハニカム・コアの幾何学}

八ニカム・サンドイッチ構造（第 5 図）の概念は， 蜂の幾何学的才能に負っていることは疑いないであろ う. その工業的製法は，日本の玩具よりヒントを得て 英国人により発明され，さらに米国において工業化さ れたとともよく知られている。

しかし蜂が最適の韵断風性を求めて六角形のパター

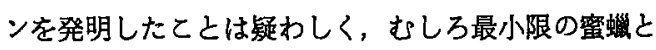
最小の労㗢という幾何学課題に完壁な解答を与えたと 考えるのが自然であるう.

この幾何学の問題はいわゆる等球のクローゼスト・ パッキング (closest packing) の問題として知られて
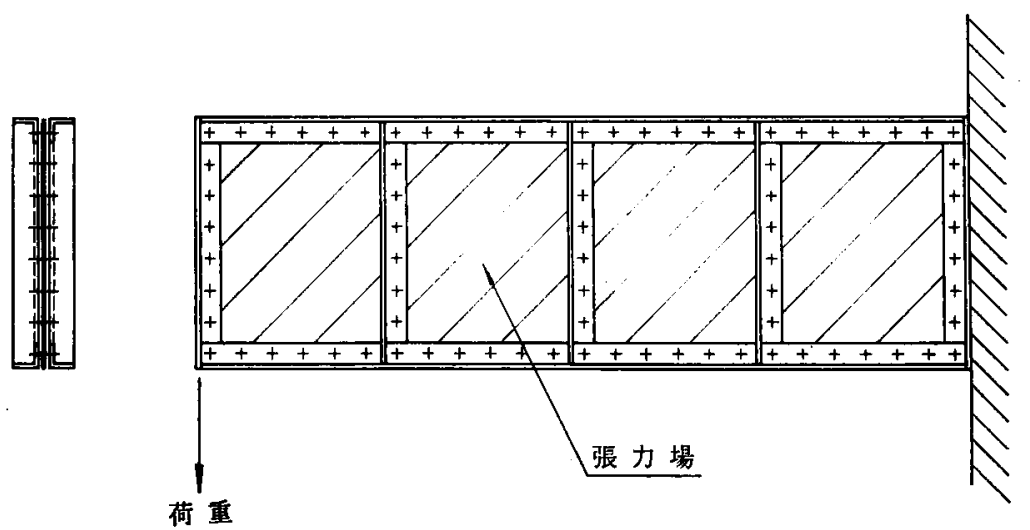

第4図 ワグナー・ビーム 


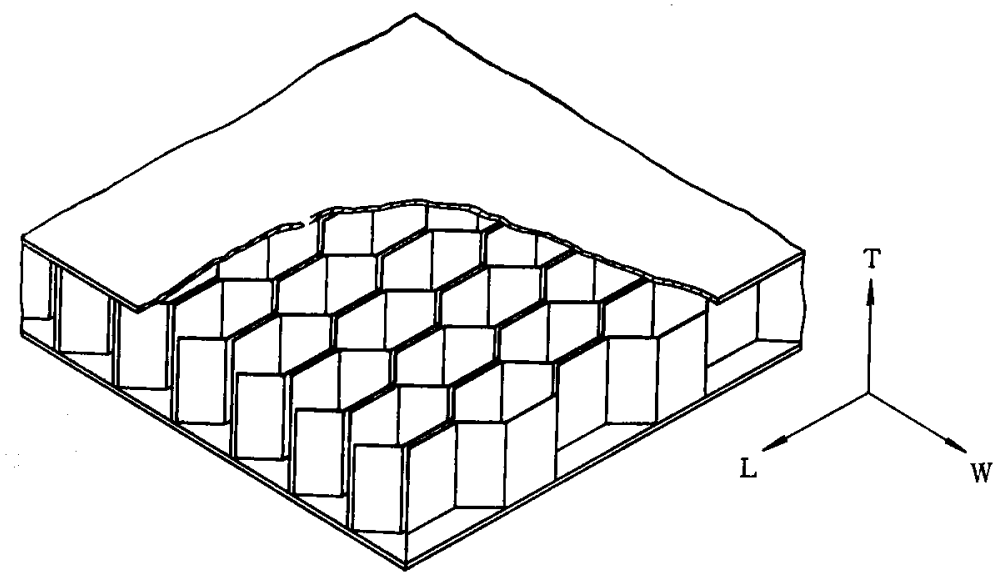

第5図 ハニカム・サンドイッチ構造
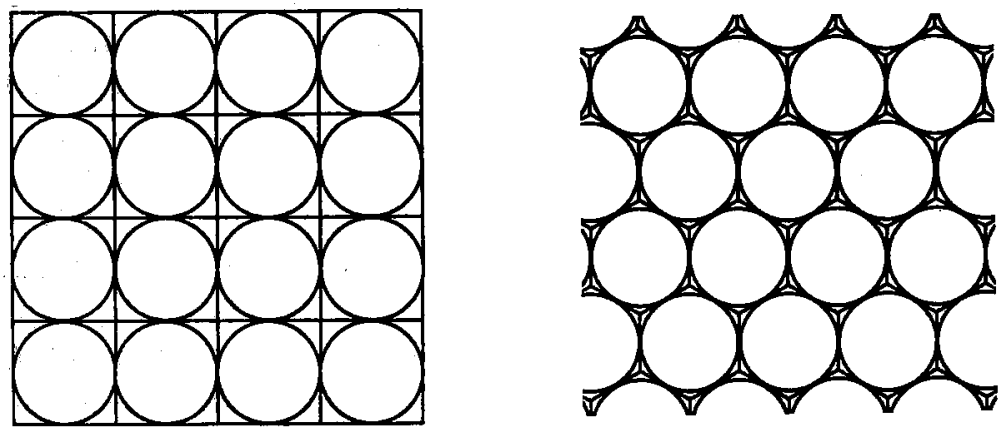

第 6 図 等円のクローズ・パッキング

いるもので，てれを二次元的な範囲で考えれば良い． 等球のクローズ・パッキングの二次元問題はさらに合 同な正多角形で平面をすきまなく埋める問題，すなわ ちレギュラー・テッセレーション(regular tessellation) または正則なタイル張りの理論と密接に関連してい る. 正 $p$ 角形を各頂点のまわりに $q$ 枚㜞きつめたテ ッセレーションは，シュレーフリ (SCHLÄFLI) の記号 $\{p, q\}$ を用いて表わすのが便利である.テッセレーシ ョンがレギュラーというのは，乙の頂点図形*が正多 角形である場合を定義とする. 実際頂点图形が正多角 形でない，正多角形のテッセレーションが存在するて 之は容易仂かる。

$\{p, q\}$ のとり得る值は，p 角形の内角すなわち $(1-2 / p) \pi$ が $q$ 個集まって頂点のまわりをすきまなく 埋めるという条件加容易に求められる.すなわち

$\{3,6\},\{4,4\},\{3,6\}$

がレギュラー・テッセレーションであり，てれ以外は 存在しない.

第6 困は等円のバッキングのニつの方法を示したも のであり，てれらはそれそれれレギュラー・テッセレー ション $\{4,4\},\{6,3\}$ の面の内接円になっている. 直観

\footnotetext{
・媔点に集まる㲽の中点を㮌に結んでできる図形
}

的に \{6，3\}の方がより経済的なパッキングであるとと がわかる.てれを明確にするために，パッキングの密 度を正 $p$ 角形 $\{p\}$ 亿対する内接円の面積比として定 義する. クローゼスト・パッキングはもちろん最も 1 に近いものとしてとらえるととができる．ての密度は $\{p\}$ の の単調増大函数であることは明らかである 加ら $p$ が大きい程よい， しかし $p$ のりうる整数值 は3,4,6であるから，pの最適値は6である. このと きの密度は

$$
0.9069
$$

になる.すなわち蜂の巣は等円のクローゼスト・パッ キングに相当することがわかった.

てのように，クローゼスト・パッキングというーつ の原理的な幾何学的条件がいくつかの決定的なかたち を排他的にきめてしまうことにわれわれは薯くべき目 然の摂理をみる思いがするのである．乙れは確かに構 造のフォルムを求める一つの方向を示していると考え ることができる.

さて「ハニカム・サンドイッチ構造は理想的な軽量 構造です」等の表現がカタログに記載されても，一般 にはあまり奇異と受け取られない程度に，これは一種 最適な構造であるとされている.しかし最適な構造と 
は一体何をもって基準とするのであろうか.上記のよ うにハニカムはクローゼスト・パッキングという見地 から最適であるてとがはっきりしているだけで，コア として最週な形状であるとは蜂の関知するとてるでは ないのである. ではどのようにして構造の幾何学的形 状の最適度の基準を量的侤表現することができるであ ろうか.

ての課題に答えるめに，こてにコアの形状の最適度 の一つの基準量として幾何効率（又は形状効率） $\mu$ を 提案することにしよう.

$$
\mu=\frac{G_{\varepsilon}}{G \alpha}
$$

こてに $G$ は使用する材料の剖断剛性率, $\alpha$ は単位体積 当たりの材料の占める体積で充筫率と名付け，G。 はコ アとしての等価剪断㓮性率である.これは次のような 考元方にもとついている．まず愬断㴊性率 $G$ なる物 質にだんだん穴を開けて軽量構造を作ってゆくとする と，乙の軽量構造の等価の剪断剛性率は次第に減小し てゅくであろうが，乙の構造は本来の $G$ の穴の部分 を差し引いた程度すなわち $G \alpha$ 程度は働いてあらわな ければならないであろう．かくて期待せる幾何効率 $\mu$ の值はとりあえず 1 に近いすのと考えることができ る. 具体的には充填率 0.5 で, 元の $G$ の 0.5 程度の $G_{c}$ が得られれば，材料は $100 \%$ 有効飞使われている之 いい得るし、これはもとをただせばコアの構造の幾何 学的形状が最適であるてとになるであるう．また

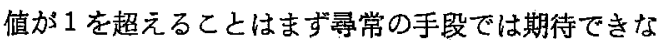
いであろう.なぜらここのよう構造を合わせてゆく 之，充填率 1 のときに元来の材質以上の剪断剛性率を 得るという矛盾におちいるからである．乙の上うな定 義によると，したがって，コアの幾何効率の最適値は $\mu^{*}=1$ として量的に規定されるのである.
しかしさらに考えを進めると，一般に $\mu$ の最適値 $\mu^{*}$ は充媜率 $\alpha$ の函数であるととが明らかとなる. こ れは次のように説明される. 第 7 a 図に示されるコア について図のように座標系をとるととにする． $\alpha$ 加1 亿近い值であるうちは，コアを構成するミクロな要素 は三次元的ひろがりをむつから，X-Z 面および $Y-Z$ 面の両方の剪断に対して働くことができる. しかし $\alpha$ が0に近つくにつれて，要素の形状はその一つあるい は二つの次元を失なわなければならないから，高々二 次元的形状の要素よりなる組織となるであろう．との ような高々二次元的な要素は，直交する二つの方向の 剪断にひとしく有効に抵抗することはできないと考え られるのである.

具体的な例を示そう. 第 7 a 図の固体に格子状の部 分が残るように四角形の穴をあけると第 $7 \mathrm{~b}$ 四のよう になる. このコアが $Z$ 軸を含む面内の純淛断を受け る場合，格子点に相当する交叉部分は $X-Z$ 面および $Y-Z$ 面の剪断にともに㗢くが，他の部分はそれが主 にある面内の剪断俥き，それ之直交する方向にはあ まり働かないであろう.との格子の $\alpha \rightarrow 0$ の極限的な 場合（第 $7 \mathrm{c}$ 図）を考えれば，格子点の部分の他の部 分に対する割合は零に収束し，その結果材料の半分ず つがそれぞれ直交する方向に $100 \%$ 有効倠く之仮定 すると， $\alpha \rightarrow 0$ のときの $\mu$ の最適值 $\mu^{*}$ の収束值は 0.5 之決定されるのである. 通常用いられるコアの充填率 $\alpha$ は 0.1 0.007 の符囲にあるととが多いから， $\alpha \rightarrow 0$ の付近の $\mu^{*}$ の持つ意味は重要である. かくて, 幾何 効率の最適值 $\mu^{*}(\alpha)$ の曲線は，一般に第 8 図のように なることは十分に根扯のあることといえよう.

さててのような基準を用いて， ハニカム・コ丁の最 適度を判定してみよう．表板の剛性が無限大とした場 合の正六角形八二カム・コ丁の等価章断剛性は赤坂・

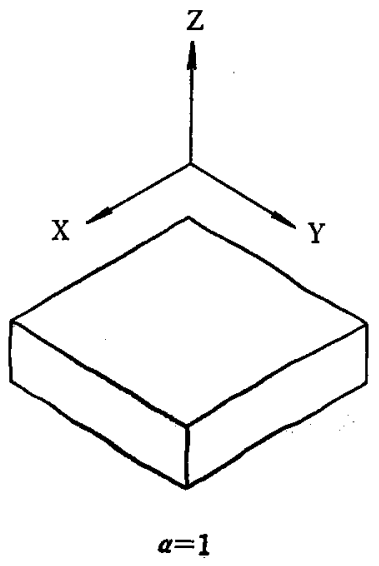

(a)

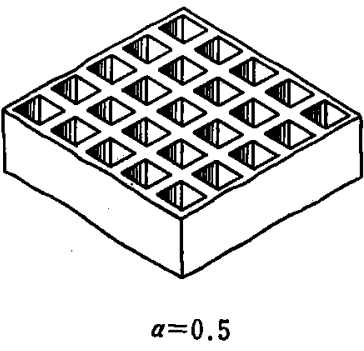

(b)

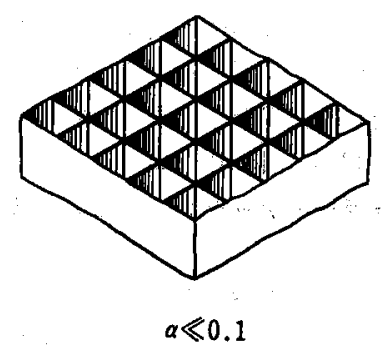

(c)

第7図 充埧率は幾何㹢率に影霹するか？ 


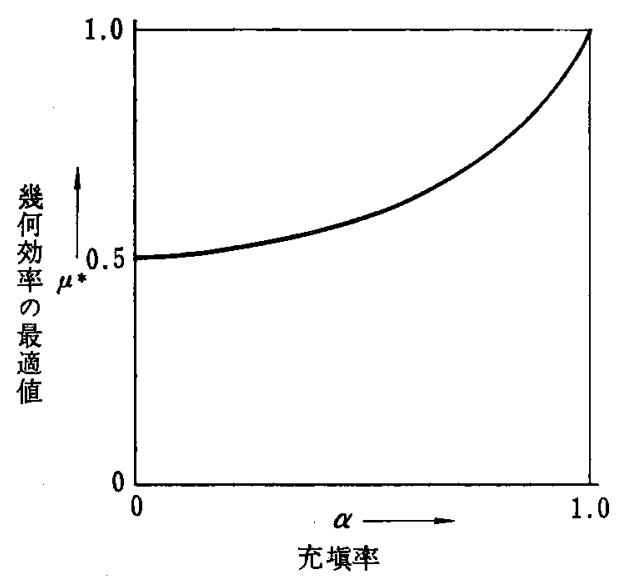

第 8 図コアの幾何効率の最適値と充填率の関係

高岸により次のように与えられている.

$$
\begin{array}{ll}
\left(G_{c}\right)_{L}=\frac{5}{3 \sqrt{3}}\left(\frac{t}{a}\right) G \quad(\text { リボン方向 }) \\
\left(G_{c}\right)_{W}=\frac{1}{V \overline{3}}\left(\frac{t}{a}\right) G \quad(\text { リボンと直交方向 })
\end{array}
$$

ここで $a$ は六角形の一辺の長さ, $t$ は簿の厚さである. また充填率 $\alpha$ は次式で与えられる。

$$
\alpha=\frac{8}{3 \sqrt{3}}\left(\frac{t}{a}\right)
$$

これより幾何効率 $\mu$ はそれぞれの方向について異なり

$$
\begin{aligned}
& \mu_{L}=\frac{5}{8}=0.625 \\
& \mu_{W}=\frac{3}{8}=0.375
\end{aligned}
$$

之計算される. 方向依存性がかなり大きいのは，八二 カム・コアの製造上の理由によりりボン方向 $(L$ 万向) に二重層を有しており，幾何学的には不完全な八二カ ムであることによる.ちなみに幾何学的に完全なハ二 カムを想定して計算をおてなうと $\mu=0.5$ となる，大 さっっ゚に考えて，上の $\mu_{L}$ で 0.5 上り增加した部分は $\mu_{W}$ の減少分に相殺されるから，八ニカム・コ丁の平 均的な意味の幾何効率はやはり 0.5 を達成していると するととができよう. ての意味においてハニカム・コ アは一種の最適な構造であるというととができよう. 現実にはしかしての目標は種々の原因により達成され ない，主な原因の一つは，一般に等方性のコアが要望 されるにもかかわらず，上記のようにリボンと直交方 向の剛性が低く，さらに実用值は低く，設計上は小さ い方の $G_{c}$ をとらざるを得ないからである.それでは 二重層のない幾何学的に完全なハニカム・コアを現在 用いられている連続なリボンによりつくれないかとい うと、てれは無論䭾目である. 実際レギュラー・テッ セレーションの中で $\{6,3\}$ のみはトポロジー的に一筆
書きのできないパターンなのである。

\section{3. 三次元ハニカム・コアの幾何学}

前節に述べたいわゆるハニカム・コアは二次元のク ローゼスト・パッキングに相当する構造であるから， てれを今後二次元八ニカム・コアと呼ぶことにする. このようにするのは，この概念の自然な拡張として三 次元八ニカム・コアなるあのが演繹的に定義されるか らである．実は自然におりる蜂の巣も，六角柱の群が 背中合せに二つの層をなしていて，一つの層は一方を 向き，他の層は別の方向に向いている. この二つの層 の内側のはまり具合は空間的な問題なのである. しか しわれわれはここで単に二つの層だけでなく，すっと 多数のセルが空間に存在する場合を考えることにす る.

てのような問題は，二次元問題の類推から空間にお ける等球のクローゼスト・パッキングの問題化㾸せら れること，そして三次元の八ニカムはこれらの球を内 接する多面体の形状となることは容易にわかる．それ ならば，そのような三次元の蜂の巣には蜂はどのよう にして出入りするのか，という疑問が脳裹をかするて あ不思議ではないであろう．との疑問に対してわれわ れは，たいへんに真面目な解答を用意することができ る. 二次元の場合の類推から，三次元の蜂の巣住む 蜂は四次元空間を飛び回っており，四次元立体である 蜂の单の境界空間，俗侸面，である境界多面体を通 って自由に出入りすることができるのである．ての論 理が正しいものであることは後で示される.

三次元のハニカムは，われわれの身近に豊富侾存在 している. パッケージング材, 断熱材, コア等に用い られている発泡プラスチック（独立気泡）は，それが 必ずしす等しい大きさの気泡からできていないととを 度外視すれは，その製造行程からして三次元のハニカ 么構造であるとすることができるであろう．末分化の 植物細胞の組織などあ良い例である。

三次元のハニカムの形状については，隋分昔から実 験的研究がなされてきた.ヘールズ (HALES, 1727 年) はえんどう豆をランダムKパッキングして加压し，そ の形状を調べた結果，これは正 12 面体であるとした. しかし正 12 面体の二面角は $120^{\circ}$ より小さいから，共 通辺のまわりに三つの正 12 面体をあわせても $10^{\circ} 19^{\prime}$ の角の隙間ができてしまう.マッヶ(MATZKE) はしゃ ほんの泡を観察して，これらは平均 13.7 面体であり， あっとあ普通なのは 13 面体でその面は四角形 1 個， 五角形 10 個，六角形 2 個よりなると報告している.

これらの実験の結果から, 三次元の八二カムの形状 のおおよそのイメージが浮かびあがるが，では理論的 
に求めるととが可能であろうか.

一つの理論的証明が四次元ユークリッド幾何学を適 用することによって得られる. ケプラー(KEPLER) は， 二次元のレギュラー・テッセレーションは無限正多面 体であると考えだ. これの類推から, 三次元のレギ ユラー・テッセレーションが四次元の無限正則胞体 (infinite regular polytope) であるとするととができ る. ことに四次元の正則胞体とは三次元の正多面体の 四次元への拡張で, シュレーフリの記号 $\{p, q, r\}$ な る四次元正則胞体は，合同なプラトンの立体すなわち 正多面体 $\{p, q\}$ をそれぞれの面 $\{p\}$ が二つの $\{p, q\}$ に属し，それぞれの辺が $r$ 個の $\{p, q\}$ に属するよう に組み合わせてできたるのである，乙の正多面体 $\{p$, q\} は，乙の正則胞体の境界空間，俗任表面，を構成 するから境界多面体之呼ばれる.

境界多面体 $\{p, q\}$ の二面角は

$$
2 \arcsin \left(\cos \frac{\pi}{q} / \sin \frac{\pi}{p}\right)
$$

であるから, 四次元胞体 $\{p, q, r\}$ が三次元空間のテ ッセレーションであるとと，換言すれば， $\{p, q, r\}$ が 無限胞体であるためには， $\{p, q\}$ が一本の辺の回りに 角のすきまなく埋めつくす必要があり，てのような角 $r$ 個の総和がちょうど $2 \pi$ でなりればならない，した がって, $p, q, r$ の間には次の関係が存在する.

$$
\cos \frac{\pi}{q}=\sin \frac{\pi}{p} \sin \frac{\pi}{r}
$$

この等式に対する整数解はあちろん $\{4,3,4\}$ だけであ る. ᄃの無限正則胞体は境界多面体 $\{4,3\}$ を一つの辺 のまわりに四つあつめたものである.角䂗糖のパッケ 一ジをあけたとき，われわれはこの無限正則胞体を見 ることができる(第 9 図).

期待に反して, 無限正則胞体 $\{4,3,4\}$ は三次元のテ ッセレーションであるにあかかわらず，てれはクロー ゼスト・パッキング，すなわち三次元八ニカムには相 当しない，何故ならば，乙の場合の密度

$$
\frac{\left(4 \pi l^{3}\right) / 3}{(2 l)^{3}}=0.5236
$$

に比較してさらに大きい密度

$$
\frac{\pi}{3 \sqrt{2}}=0.7405
$$

がざくろ石の結晶として自然界化存在するひし形 12 面体の内接球を用いて得られるからである。，またロジ ャース (ROGERS) によりとの密度の上限が 0.7797 で あることが証明されている.それゆえ三次元の八二か ムというるのか存在するとしたら，その密度は0.7405

*シュレーフリの琼号 $\{p, q\}$ が，正多面体にあ二次元レ ギュラー・テッセレーションにす均しく適用できる理 由はここにおる.

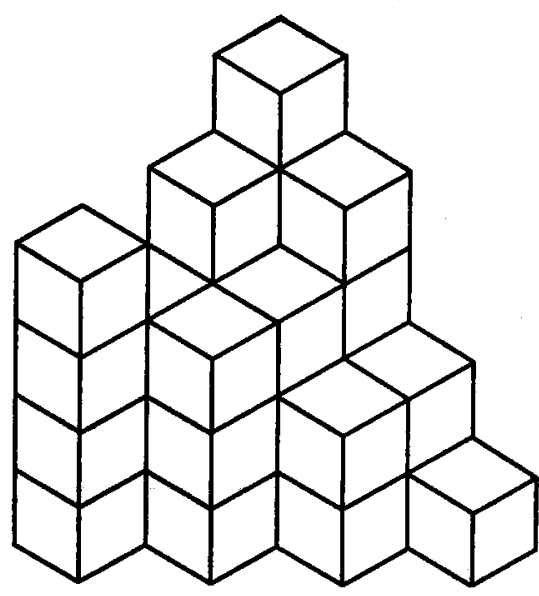

第 9 図 然限正則胞体 $\{4,3,4\}$

から 0.7797 の間の値をとるべきなのである.

空間において，四つの等しい球を最む密にパッキン グするには，すべて互に接するようにすれば良い，そ れ以上の球を追加するには，乙の操作を綝返すてとが 最あ密なパッキングを作って行く方向であるとする考 えは自然であ万う．最初の四つの球の間に形成される 頂点四形は $\{3,3\}$ であるから，この繰り返しでできる 胞体は $\{p, 3,3\}$ であるてとは確からしい，しかしな 加ら前記 $p, q, r$ の関係式は $q=r=3$ のとき整数解を もたない，換言すれば，上記のような操作を続けると 遂には球と球の間にすきまができてしまう.一方実験 の結果はすべて p が5から6の間の值をとる正則胞 体 $\{p, 3,3\}$ を近似しているように思われる.

そこで少し無茶であるが p が整数であるととを放 萧して, $p, q, r$ の関係式を $q=r=3$ としてそのまま 解いてみる。

$$
\sin \frac{\pi}{p}=\frac{1}{\sqrt{3}} \text { または } p=5.1044
$$

また境界多面体 $\{p, 3\}$ は平均して $F$ 枚の面よりなる として, $p$ と $F$ の関係式により

$$
F=\frac{12}{6-p}=13.398
$$

となる．との結果は，五角形の場合が最も多く，六角 形の方が四角形上り頻度が多いとと，面の数が 13 之 14 の間にあるという実験事実の驚くべき裹付けとな っている. pが整数でないとと，F整数でないとと は，三次元のハニカムが統計的な意味でのみ存在する ととを示しているように思われる。

サンドイッチ構造のコアとして用いられている発泡 体为，上述のような幾何学的形状を有することが明ら かとなった.とれがコアとして最適な形状をしている かを絤討しよう: 種々のプラスチック発泡体のデータ より幾何効率 $\mu$ を計算すると, $\mu$ は $0.1 \sim 0.2$ の箐围 
にあるようであり，最適値からは程遠いととが示され る.とれは次のように解釈することができる，発泡体 は巨視的には均犋な三次元物体であるが，充填率 $\alpha$ が 0.1 以下であるとすると，コアのミクロな要素は高々 二次元的ひろがりすなわち面よりなり，それぞれの要 秦は一つの面内の愬断にのみ働くようとなり，とれら の統計的な和か巨視的な特性を決定する. 結局 $X-Z$ 面， $Y-Z$ 面， $X-Y$ 面のそれぞれ一方向には材料のそ

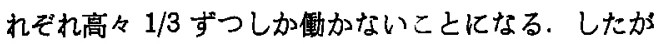
って期待し得る最高の幾何効率 $\mu^{*}$ は $1 / 3$ なのである. 三次元テッセレーションである第 9 図の形状のコアに おいて，その正六面体のうちそれぞれ二面がその方向 の算断に $100 \%$ 䱂き，他の四面は全く働かないから， これは確か炕幾何効率の最適值 $1 / 3$ を与えるととがわ かる.

サンドイッチ構造のコアはあともと直交する二つ の方向の剪断剛性を与えれば良いのであるが，発泡体 はさらにてれらと直交する方向の無䭾な剪断剛性をつ くりだしているのである. そしてての性質は全くコア の幾何学的形状淿せられるべきすのなのである．し たがって，将来発泡体の幾何学的形状を制御するとと ができれば，より効率的なコアの構造のフォルムを作 る指針はこの議論で明らかに示されているといえ。 う.

\section{4. 単一板よりなるコアの幾何学}

2 節において，自然存在する完全なハ二カ厶構造 に対して，われわれの工業的に作るすのは幾何学的に 不完全八二カム構造であるてとを述へた．このととは その材料之製造法において自然と人間との美異を示し ている. 工学的に最適な構造のフォルムは，材料消整 の経済性のみならず，供給材料，経済的加工法等多く の条件を包括した最適化でなりればならないのであ る. したがって一方では性能を重視する傾向に対し て, 構造の単純化を特佁調するコアのフォルムが求 められるととは当然であろう.こてに単一面のトポロ ジー的変換によるコアなる概念が登場する機会が与え られるのである.

一体サンドイッチ粠造におけるコアの役目は何であ ろうか. “軽構造の理論とその応用”によると“二枚の 表板の結合媒体として，それらの支持および安定化の 機能”とある. そこで，コアとしての必要十分な機能 を発揮できる考元得る限り最む単純な構造は，単一板 のトポロジー的変换によっててれを達成するすのでは ない加と思われる．とてにトポロジー的変換とは極め て伸び易いゴムのような材料を考えて，その位相幾何 学的性質が変わらないような変換と定義する.
この種コアの代表的なものは，コルゲーション・コ アと呼ばれるるので，段ボールはその最も早近な応用 例である.コルゲーション・コアは確かに二枚の平行 な表板の間を往復する単一板よりなり，加工は簡単で あり、コてとしての優れた機能を有している．しか し，次点はその極端な異方性にあり，これが使用上の 一限界を規定するのである.

最近第 10 因に見られるような楕円函数のレリーフ を彷彿させるコアが米国で発明され工業化されてい る.これはまさに筆者のいう単一板のトか゚ロジー的変 換によるコアのカテゴリに入るもので，てれを見せら れたときは少なからず䉆かされたすのである，発明者 がどのような思考過程でとのコアの幾何学に到達した かはもちろん知るところではないが，乙れは仮想的に 次のように説明するてとあできよう。

すなわち，コルゲーション・コアの異方性は一方向 にのみ周期性を有する形状化基くすのであるから，こ れを改善するには直交二方向に周期性を有する形状と すれば良いであろう.これは第 11 図で $f$ を連続・— 価・有界の周期函数として

$$
\begin{array}{ll}
Z=f_{X Z}(X) & (X-Z \text { 面内 }) \\
Z=f_{Y Z}(Y) & (Y-Z \text { 面内 })
\end{array}
$$

の二つの函数の皘

$$
Z=f_{X Z}(X) \cdot f_{Y Z}(Y)
$$

のようなあのを考元れば良いであろう，われわれはて の種の函数には，主として板の撓み変形などの弾性問 題で親しんでいるから，ての上うな考え方が最も自然 であろう. 確汃にとのコアは上記の函数型と定性的に 近いものとなる.

とのコアの一つの興味ある幾何学的特性は，その製 造法々関連するものである. 熱可塑性プラスチックの 平板を加愁し軟化させた状態で，その両面に交互にず れた位置の格子点状隹対置した多数の丸棒状突起によ りプレス成型するあのである。これはまさにトポロジ 一的変換を現実に行なったあのである．加熱したプラ

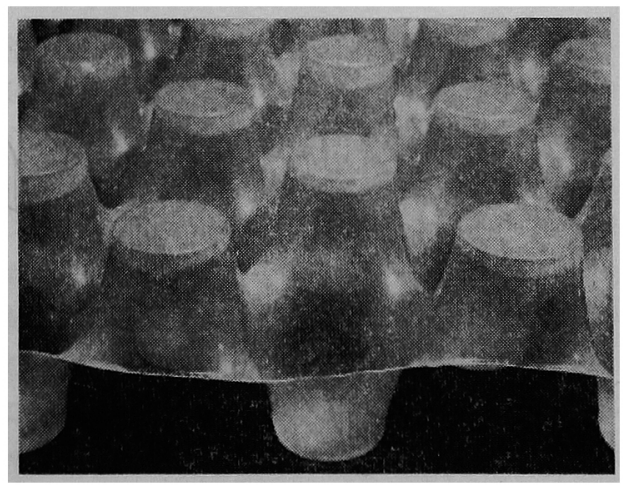

第10因単一板よりなるコアの一例 


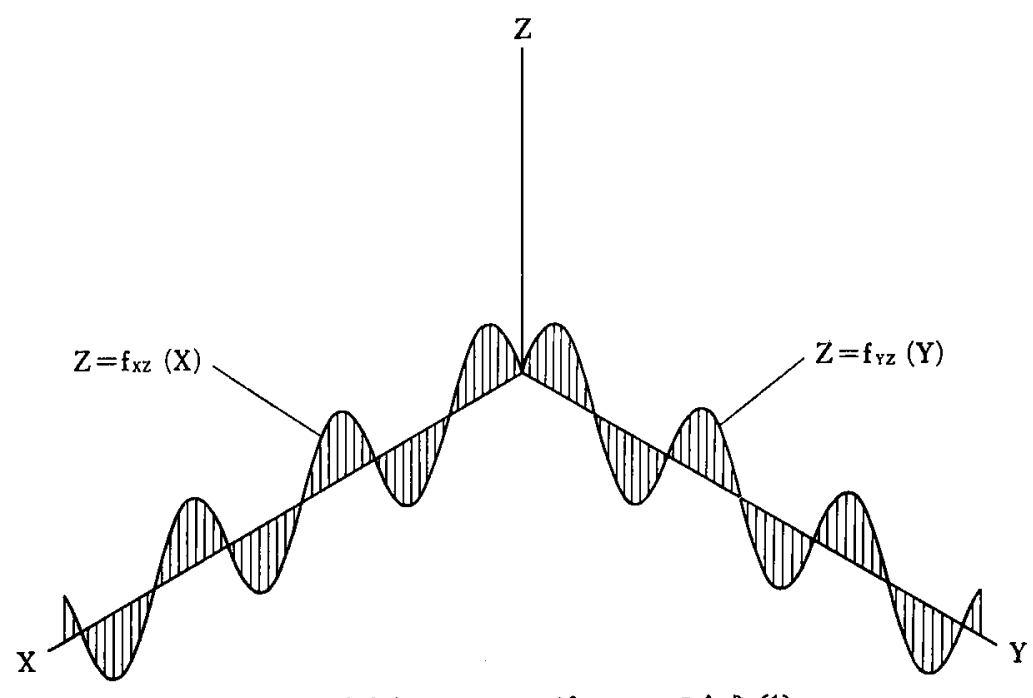

第11図 直交する二つのコルケ゚ーションの合成 (1)

スチック板は，そのとき近似的に薄膜の状㦔であると すると，乙の形状は最小曲面に近いすのになるはずで ある。

その着想, 幾何学的形状の面白さから離れて, 構造 のフォルムとしての適性を調べると，現実は意外飞喛 しいととがわかる．当初の着想がコルゲーションを重 畳するととによって特性を改良するととにあったとす るならば，結果として重疊されたあのがメリットであ るかデメリットであるかの疑問に到達してしまうので ある.

人はてれによるサンドイッチ構造を事実上直線部分 よりなる立体トラス構造として捉えようとするが，て れは大分怪しい，その理由は，乙れが最小曲面である ことを受入れるならば，微分幾何学の法則の教える之 ころによると，いたるところ平面でないかぎり直線部
分は存在するはずはないからである.むしろいたると ころ負のガウスの曲率の曲面であり，通常のコアとし ての荷重状態では面内応力だけでなく望ましくない曲 げ応力が生ずるのはほとんど避け難いのである.

\section{5. ダブル・コルゲーションコアの幾何学}

平面をその直交二方向にコルゲーションさせるとい う命題に対して，われわれはほとんど条件反射的に

$$
Z=f_{X z}(X) \cdot f_{Y z}(Y)
$$

なる函数を想定するであろう. 板の曲げや挫屈につい て二重級数の使用に慣らされてきたあとではなおのと とこの方向への傾斜任抗し難い，構造のフォルムを 創造する仕事にとって，いかにての上うな固定観念が 邪魔になるかを筆者は示すことができる.

実は上記函数以外にあ平面を直交二方向にコルゲー

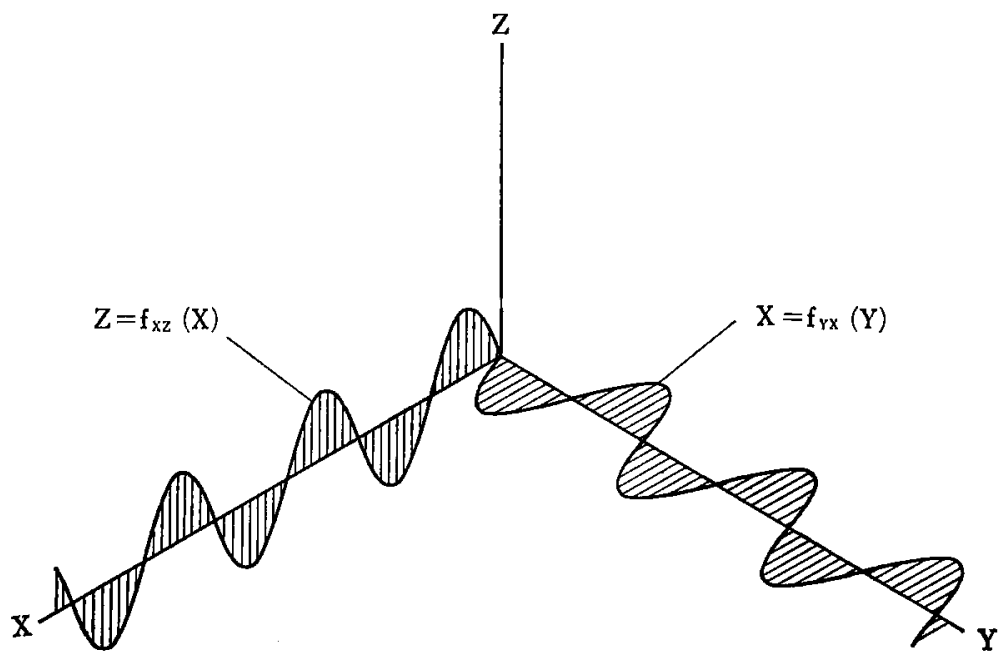

第 12 四 直交するニつのコルダーションの合成 (2) 
ションさせる良い方法があるのである。第 12 図にお いて我々は $X-Z$ 面认は前と同様に周期函数 $f_{X Z}(X)$ を考元上う. しかしあう一つの周期函数としては $Y$ $Z$ 面ではなくて，X-Y 面の周期函数 $f_{Y X}(Y)$ を考元 る. いま曲線 $f_{X z}(X)$ をその曲線上の固定せる一点が 曲線 $f_{Y X}(Y)$ 上を進むように併進させるときに描加れ る曲面

$$
Z=f_{Z X X}\left[f_{Y X}(Y)\right]
$$

は確かに直交二方向に周期を有する函数をあらわし， しかる振幅が一定の周期函数を用いることによって， 二つの平行平面の内側に内接する曲面となる，なお筆 者はこの種の曲面の総称として《ダブル・コルゲーシ ョン面》*を仮に用いている.

ダブル・コルゲーション面は，その周期函数のかた ちによって多種多様の形状をとり得るが，ててではそ の中でも最も美しい幾何学的関係を有する曲面を紹介 しよう.とれは第 13 図および表紙写真に示される図 形で，二つの周期函数としてともに鋸菌型函数を用い る結果生ずる. 一見結晶のような規則正しい美しい形 状であり，実際幾何学的にも不連続群としてはっきり 規定することができる.すなわち，第 14 四は四つの 合同な平行四辺形からなる基本領域で，ての基本領域 の二つの独立な併進加ら生成される群 $\boldsymbol{p} 1$ として，ダ プル・コルゲーション面を表現することができる．さ らに任意の頂点にあつまる四つの角の和を調へるとて れはちょうど $2 \pi$ であり，したがってての面は展開可 能面であるという㢣くべき性質を有するととに気付く のである.

展開可能面であるがゆえに，そして紙は展開可能面 にしか折られないゆえに，乙の形は折紙や造形の世界 ではかなり以前から知られていたらしい，英国人で紙 彫刻の専門家サドラー (SADLER) の著書には “影ひだ 折り”としてての形が紹介されている. との形を最初 にサンドイッチ構造のコアとして考えたのは，フラン

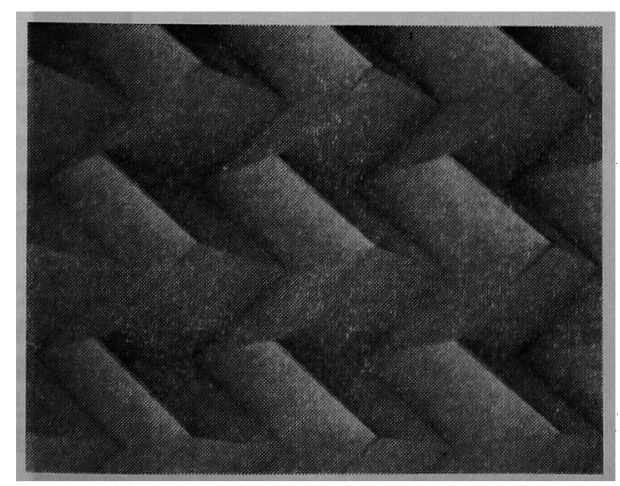

第13図可展ダブル・コルゲーション面

* double corrugation surface

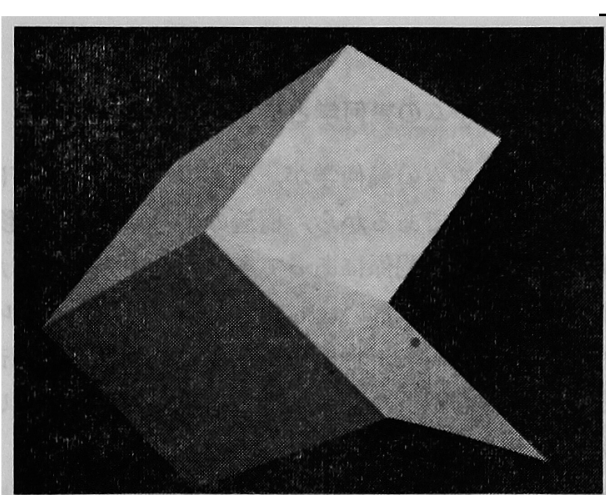

第 14 図 可展ダブル・コルゲーション面の勘本領城

ス人か最初でありその目標は殷ボールの中芯にあった らしい，しかしながら，恐らくはその工業的製造法の 困難さ之，構造としてのメリットの評価ができないた めに，構造のフォルムとしては受入れられず，単なる 継の造形の遊びとしてしか生き延びないように見え る．あちろんそれが美しい幾何学を内蔵するすのであ ることあ全く知られずに，その存在は今や失なわれよ うとしている.

筆者はこの“影ひだ折り”を特殊な例として含む一 般のダブル・コルゲーション面について，それをコア・ ジオメトリイに適用した場合の解析を行なった．てれ は本稿と前後して出版される論文化詳細化述べられて いるので，こてではこの特殊例についてその基本的な 性質を説明しょう.

まず直交デカルト座標を適当にとると，基本領域を 構成する四つの平行四辺形面の法線ベクトルの方向余 弦 $l, m, n$ はそれぞれの平行四辺形について絶対值が 等しい1租で表現することができる．なかんずく $Z$ 軸 との方向余弦 $n$ は 0 であ 1 であない. との $n$ が 0 であ 1ですない面が分布して存在することてそ，実にての コアの構造特性を決定付けるのである，すなわち八二 カム・コアの場合は各構成面はすべて $n=0$ であるか ら,コア全体が巨視的に尊断変形を生じた場合各構成 面に生ずる変形す純粹鹊断変形である．しかるに今の 場合は $n \neq 1,0$ であって表板に対して粠成面はすへて ある傾きを持っており，てれに生ずる変形は純粋剪断 変形ではない．またこの空間に傾いた面は 4 種類が分 布していて，全体的には統計的な和として墈くから， 一つの方向に対して特に等価整断剛性が小さくならな いように面をきめることができる．理論的には，幾何 効率が 0.5 亿近い形状を設計できるととがすでにわか っている.

ての特別な例に見るように，一般に“ダブル・コル ゲーション・コア”はハニカム・コアに氏敵する幾何 効淬を，単純な単一面のトポロジ一的変換によって達 
成している全く新しい構造のフォルムなのである.

\section{6. フォルムの幾何学とデフォルメの幾何学}

構造のフォルムの幾何学が，構造の根元的な性質に よっているあのであるから，構造のデフォルメ(変形) の幾何学と密接な関俰にあっても，考えてみればあた りまえなのかすしれない. しかし，上に導いたダプル。 コルゲーション面と, 平板やシェルの挫屈問題との奇 妙ともいうべき結びつきには誰しす第かされるに違い ない.

前節に示した特別なダブル・コルゲーション面が展 開可能面であることはすでに述べた.つまり第 13 困 のモデルを展開して行くと完全に平面になり，逆に平 面から折り込むと元に戾る．幾何学ではこのように互 に展開可能である二つの面は等長 (isometric) である と呼ふ. また一つの面から他の等長な面への変换を等 長変换 (isometric transformation) 之呼ふ. また等長 な面相互では，その曲面上の幾何学，別の言架で内的 幾何学 (intrinsic geometry) を取り扱う限り，てれら は全く同一であり区別できない，内的幾何学は曲面の 第一基本量だけによってきまるすので，第一基本量 gas は等長な面ではたがいに対応する点で等しい，ま たは等長変換によって変わらない， $g_{\alpha \beta}$ は曲面上の長 さの計量にかんにする量だから，てのととはこの種の 曲面を中央面とするシェルの面内歪は，そのような等 長変换によっては生じないということになる。

さてここで，ダブル・コルゲーション面の紙モデル を，少なくとすその基本領域の分だけ作っていただけ れば説明が簢単になる．そのような紙モデルを用いて 平面いダブル・コルゲーション面の変換を行なえば 容易にわかるが，稜線の面角を小さくすることによっ て，平面加らダブル・コルゲーション面にする操作を 極限まで続りると，てれは一つの方向にペシャンコに つぶれると同時に，これと直交する方向にあ収縮が起 きているのがわかる，てのような折り方は，結局平面 を直交二方向に同時に㥜み込むことになるのである．

これは扇子やアコーデオン・ドアが唯一つの方向にの み畳み込めることと対比されよう．このような直交二 方向の畳み込みによると，理諭的には平面を一点に絞 り込むことが可能である，その条件は上記基本㴿域が 無限に小さい四つの短形加らなるとき，換言すれば， 平面を限りなく組かい直交将子で分割しその格子線に それぞれの回転の方向を指定することによって踹たさ れる.

読者は，薄肉円筒を聑方向に押しつぷしたときに， あるいは曲げたときにその正維側に，生ずる菱形の回 みを観察された経験があるであろう．ての基本的なパ
ターンは，限りなく薄い円筒殼という理想化された条 件のあとに，いわゆる吉村パターンと呼ばれる凹多面 体面となるととあ知添しておられるであるう（第 15 図).この形は，やはり展開可能面であるがゆえに， 折紙や造形の世界では古くより知られていた形であ り，デンマーク製のランプ・シェードのデザインとし てわれわれの身近にあある.

吉村パターンを純粋に幾何学的な間題としてとら え，乙の種の凹多面体面の一般化を行なう之，とれは 次のように記述される，任意の柱面を $S$ と名付ける. この $S$ に際限烸く近接し，これと等長であり，軸方 向に一様な縮みを有する面 $S$, が存在する. この面 $S$, は凹多面体面で，無限に小さい一対の三角形または台 形よりなる基本領域で生成される. 面 $S$ より $S$,の 変换は等長変換で行なわれることは明らかで，そのと きとれをシェル中央面と考えればシェルの面内歪みは 生じないととすすでに述へた．無限に薄いシェルの変 形は，エネルギー論的に考えると，できるだけ面内雪 みを避け，曲げ歪みを生ずるように行なわれるはずで あるから, 面 $S_{p}$ 少薄いシ ェルの挫屈変形としてあら われるのあこの理由なのである. 通俗的にいう之て の等長変換は柱面を䋡に畳み迈むことであり，パター ンの形状によって任意の縮み量を選べるから，理論的 に軸長零まで押しつぶすととが可能である.

ことまで来て，ダブル・コルゲーション面という構 造のフォルムの幾何学之，柱面のデフォルメの幾何学 との奇妙なかんけいにわれわれは驚かされる.ダブル ・コルゲーション面は平面の等長変換による二方向の

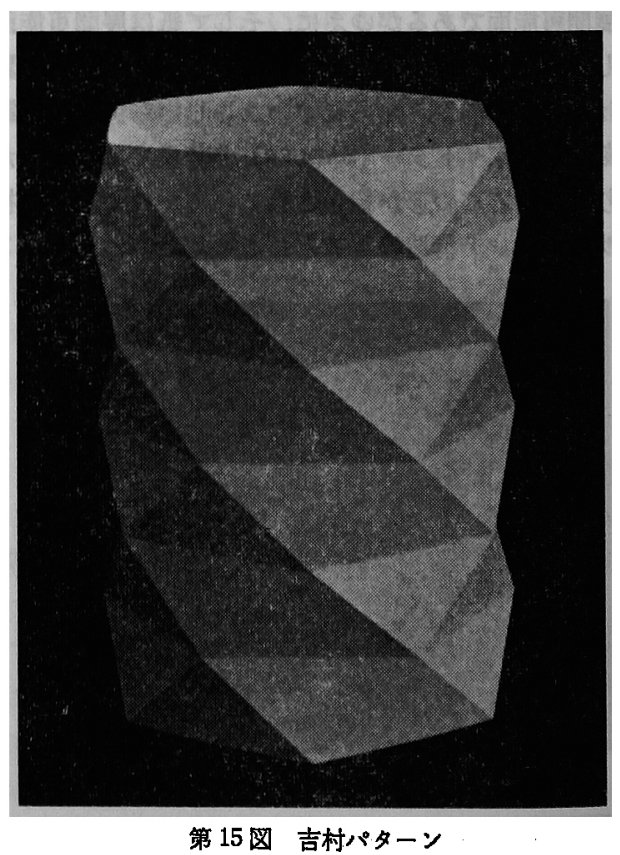


胃み迈みによりできる形であり， $S$ ，面は柱面の同栐 な一方向の畳み込みによる形である，実際前者は後者 の特別の場合としても定義することができる．

柱面のデフォルメからの類推により，ダブル・コル ゲーション面は，無限に大きいと同時に無限に薄い平 板の二方向圧縮による不伸張挫屆変形であると信ずる とともできよう．しかしこれに相当する奇麗な条件は 円筒の場合と異なり現実になかなか満たされないか ら，容易観察することはできないであろう*.

一方吉村パターンで代表されるデフォルメ，すなわ ち面 $S$ ，は構造のフォルムとして用いられることを忘 れてはならないであろう．乙の種凹多面体面は，軸方 向にいわば破壊せるかたちであるが，これを中央面と するシェルは軸に垂直な方向に対してもとの円筒殼よ り大なる剛性を有する．乙れを利用して，要素が単純 な三角形であるととあ助けとなり，半円形ドームの建 筑物がすで作られているのである.

これらの事実は，構造のフォルムを創造するには王 道は無いというととをつくつくわれわれに思い知らせ ると同時に，構造のフォルムの創造がデフォルメの現 象を解きあかすこともあるという，功ちらの法則の神 秘性を教えるかのようである.

\section{あとがき}

本稿を用意するにあたり，以下の本および論文等を 参考にしました. 主なあのは 1,2,5,6,11 です.

莯何学一般

*老人のひたいのしわは，退化し二方向に収縮する頭が い骨と，不伸張変形しかできなくなった老化した皮周 によって作られるダプル・コルゲーション面であるか あしれない。地球のしゅう曲，紮料のちりめんじわ等 々この条件に近いものはいろいろありそうである.
1. Hilbert, D. und Cohn-Vossen, S., Anschauliche Geometrie, Verlag von Julius Springer, Berlin, (1932)，邦訳「直観幾何学」，みすす措层，(1960).

2. Coxeter, H.S.M., Introduction to Geometry, John Wiley \& Sons, Inc., New York, (1961), 邦 歌「为何学入門」, 明治图書 (1966).

3. WeYL, H., Symmetry, Princeton University Press, Princeton, (1952)，邦訳「シンメトリー」，紀伊国屋 (1957).

ハニカム

2. 前出

4. Akasaka, T. and Takagishi, T., "The Shear Modulus of Foil Honeycomb Sandwich Structures", Trans. Jap. Soc. Aero. Space Sci., Vol. 2, No. 3, pp. 83 (1959).

ダブルコルゲーション面

5. Mrura, K., "Proposition of Pseudo-Cylindrical Concave Polyhedral Shells", Symposium on Folded Plate Structures, International Association for Shell Structures, Wien, 1970.

6. Mura, K., "Double Corrugation Surface and it's Application to Sandwich Structure", (To be published.).

7. SAdLer, A., Paper Sculpture, Blandford Press, London, (1964).

8. Londengerg, K., Papier und Form, Scherpe Verlag Krefeld, (1963).

吉村バターン

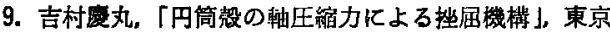
大学理工学研究所報告, 第 5 巻, 第 5 号, 179 貢 (1951).

10. Mura, K., "Inextensional Buckling Deformations of Genera! Cylindrical Shells," AIAA Journal, Vol. 6, No. 5, pp. 966, (1968).

フォルムとデフォルメの挑何学

11. Mrura, K., "Proposition of Pseudo-Cylindrical Concave Polyhedral Shells," Inst. Space \& Aero. Sci., Univ. of Tokyo, Report No. 442, (1969).

なお本稿をいくらかでも読み易くするための各種の 写真・イラストは酒巻正守氏の協力によってできたす のであります。

\section{表紙写真説明}

これは平面を，その面が伸びたり縮んだりすること なしに，直交二方向に同時に押し潰すときにできるか たちである. この面は可展ダブル・コルゲーションと 名付けられ，極めて美しい幾何学的性質を有している. 例えばてのある種のあのは，平面を一点にしに゙り込む ことが理諭的に可能である.

可展ダブル・コルゲーション面は，その導入過程よ りして破䚂せるかたち。すなわち“デフォルメ”であ るか⿰力口奇妙なととに新しい榑造の“フォルム”の基本 型を与えるのである.とれをサンドイッチ構造のコア として用いると，ハニカム・コアに匹敵する幾何効率 を示す.

写真は，モデルの斜上方より単一光で照明して振影 したもので，明るいシグザグ線は谷，暗いジグザグ線 は山に相当する.

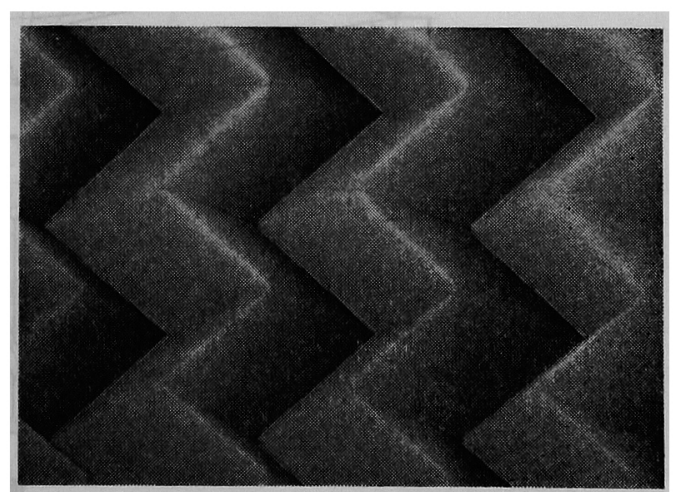

(本誌講座, 構造のフォルムと幾何学, 6 節 “フォル ムの幾何学とデフォルメの幾何学”参照)

(三浦公亮) 